\title{
Urban Agriculture in Arusha City, Tanzania: Misconceptions and Realities
}

\author{
Pastory Salvatory Thomas ${ }^{1, *}$, Wilbard Jackson Kombe ${ }^{2}$, Aldo Lupala ${ }^{3}$ \\ ${ }^{1}$ Department of Crop Science and Horticulture, Faculty of Agriculture, Sokoine University of Agriculture, Morogoro, Tanzania \\ ${ }^{2}$ Institute of Human Settlements Studies, Ardhi University, Dares Salaam, Tanzania \\ ${ }^{3}$ Department of Urban and Regional Planning, School of Spatial Planning and Social Sciences, Ardhi University, Dar es Salaam, Tanzania
}

Email address:

pastory.thomas@sua.ac.tz (P. S. Thomas), kombewilbard18@gmail.com (W. J. Kombe), aldo.lupala@aru.ac.tz(A. Lupala)

${ }^{*}$ Corresponding author

\section{To cite this article:}

Pastory Salvatory Thomas, Wilbard Jackson Kombe, Aldo Lupala. Urban Agriculture in Arusha City, Tanzania: Misconceptions and Realities. Urban and Regional Planning. Vol. 6, No. 3, 2021, pp. 93-100. doi: 10.11648/j.urp.20210603.12

Received: July 21, 2021; Accepted: August 2, 2021; Published: August 11, 2021

\begin{abstract}
Like many cities in Sub-Saharan Africa, urban agriculture in Arusha city is perceived differently by urban land decision makers, agricultural and environmental officers as well as urban farmers. The way urban agriculture is perceived changes depending on urbanization rate and institutional framework of cities' authorities. Despite that situation, information on how positive perception can lead to the prosperity of urban agriculture or its negative perception can hinder its prosperity is still implicit. Thus, this study was conducted to examine the perception held by urban farmers and officials in Arusha city and the way such perceptions affect urban agricultural activities. The study adopted a qualitative research approach in order to gain the in-depth respondents' opinions and perceptual information about urban agriculture. The case study strategy was deployed by this study because the perceptional thoughts held by respondents on urban agriculture depend on the actual situation through which agricultural activities took place. A total of 60 respondents were exhaustively interviewed. Other information was obtained through observation as well as reviewing literature. All data obtained were analyzed and interpreted based on their content. The findings revealed that some of the negative effects caused by urban agricultural activities influenced the negative perception people held on it. Those effects were seldom managed by officials from Arusha city authorities. However, some of those effects to the environment and urban development were evident, they were sometimes exaggerated due to the negative perception already existing in the city officials' minds. The positive perception of urban agriculture existed only when its associated benefits met the interests of the urban farmers and city officials. The study concludes that, the positive or negative perceptions of urban agriculture has close a relationship with the livelihoods of the farmers and the employment needs of officials such as urban planners, environmental officers and agricultural officers. Despite urban agriculture being somehow acknowledged in the policy documents, the effects of negative perceptions among different stakeholders about urban agriculture are considered less crucial in the policy implication and other formal governmental proclamation. However, in the reality it is critical.
\end{abstract}

Keywords: Urban Agriculture, Perception, Misconceptions, Realities

\section{Introduction}

Urban agriculture involves keeping livestock and growing edible crops and non-edible plants such as ornamental plants. It is practised to obtain food and income earning, green urban areas or conserve the environment. However, the value it generates and the adverse effects it has on human beings and the environment are perceived and interpreted differently [27,
31, 14]. The way farmers grow crops and keep livestock in urban areas and the regulation of these activities using bylaws and national regulations always change [1]. One might think that by-laws and policies are meant to promote agricultural activities, while another might think that they are oppressive to urban farmers [21]. Despite the problems and negative effect it has on the environment and public health $[1,27]$, it is acknowledged that it provides livelihoods to people who are engaged in it [22]. 
Urbanization of the cities in Sub Saharan Africa and the rampant conversion of former agricultural land into housing casts a doubt on the way officials and other decision makers in the cities perceive agriculture and devise mechanisms to promote it $[13,4,36]$. Although, the contribution of agriculture in terms of food is somewhat evident, opinions about its importance vary $[17,11]$. The role of urban agriculture in ensuring food security and in generating income for the poor is underrated while at the same time exaggerating its negative effects on the environment [20]. The decline of the size of land for agriculture in urban areas is caused by large-scale house and commercial building construction [18, 12]. This, however; cannot be critically analyzed without understanding what relevant policies say about agriculture. In the Tanzanian context, documents such as the Urban Planning (Urban Farming) Regulations of 2018 and the Human Settlements Development Policy of 2000 recognize agriculture as one of the activities done on urban land [33, 35]. However, even if the policies relevant to urban agriculture were good, would not be effectively implemented if people had a negative perception of urban agriculture [5].

The formulation of supportive policies and the removal of regulatory barriers to agricultural activities are directly related to the ways in which urban agriculture is valued in terms of its benefits [12]. For example, the peoples' positive perception of urban land use planning for housing stemmed from their interest in having decent houses and socioeconomic services $[24,36]$. In normal life, individuals perceive things in relation to their personal interests [6]. In decision-making process involving various stakeholders, it is wise to analyse their opinions on the basis of their interests first and then reaching conclusions because the conclusions might be induced by personal needs, irrespective of real life situation [6]. In Columbus, urban farmers' positive perception of agriculture was influenced by the food and income they got from agriculture [14]. Moreover, farming rules and regulations imposed by the authorities of Columbus City on land use zoning for non-agricultural activities are regarded as a restrictive and great barrier to agricultural prosperity [14].

In Accra, land for agricultural activities was inadequately taken into account in land use planning owing to limited awareness about its contribution to food and income among people who live in urban areas [25]. Recently, the studies done in Tanzanian have inadequately shown the influence of awareness on perception, especially in the field of urban agriculture. The factors such education, life hardships and interests of the people which influence either positive or negative perception of agriculture are not universal [14]. Rather, they change with time in relation to urbanization and people's lifestyle [6].

Globally, in the 1970s, the International Labour Organization (ILO) and the Food and Agricultural Organization (FAO) excluded urban agriculture from the definition of informal-sector activities because it was perceived to have insignificant contribution to people's income and food stock [8, 7, 21]. The food produced through urban agriculture did not qualify as food security because food security implies that food is easily available, accessible and affordable of food in sufficient quantities and quality [22].

In the 2000s, African countries such as Kenya and Tanzania recognise urban agriculture as a compliment to urban food security and source of income for the urban poor $[19,7]$. Although the value of urban agriculture being somehow evident, the way it is supported practically differ in from country to country and among different stakeholders $[23,28]$. Institutions responsible for developing urban land uses and food systems in sub-Saharan African countries are aware of the value and negative effects of urban agriculture, but they focus less on solving problems associated with access of land for agricultural activities [37, 16, 30]. In some African countries, including Tanzania and Zimbabwe, the pace at which urban agriculture is promoted and supported is not promising $[15,10]$. In relation to that, $[29,21]$, say that peoples' perception of urban agriculture is neutral when management does not promote or discourage it. In Botswana, urban agriculture was perceived negatively by local and central government officials, because it limits the full and potential utilization of urban land in a more economical way [23]. Sometimes, urban agriculture is negatively perceived, but this perception is exaggerated without the empirical justification [14, 26]. In Lisbon and Baltimore, urban agriculture is part of the urban fabric and is supported because the city officials are aware of its role in environmental protection and of the ways in which it supports the livelihoods of the urban poor [17, 3].

In the Tanzanian context, unlike in the 1980s when urban agriculture was considered illegal, since the $2000 \mathrm{~s}$, it has recognized to some extent subject to fulfilment of the conditions set by the policy and legal documents [34, 11]. This recognition is based on the fact that the urban population in Tanzanian cities is facing unemployment and food insecurity, which could partly be addressed by urban agriculture. This recognition notwithstanding, farmers in Dar es Salaam still face problems relating to land and agricultural inputs and infrastructure [30,21]. This study was undertaken to examine diverse different stakeholders' perception of urban agriculture, the cause of this perception and the extent to which it can make people or institutions support or impair agricultural promotion in relation to other non-agricultural land uses.

\section{Materials and Methods}

\subsection{Area of the Study}

This study was conducted in Arusha City, Tanzania. In the city, crop cultivation and animal husbandly are widely practised in all 25 wards, although to different degree and purposes. The city is also urbanizing rapidly and the urban population provided a niche market for agricultural products. Specifically, this study was conducted in the wards of Daraja 
Mbili and Lemala. The wards were chosen because agriculture is one of the dominant land use activities in these wards. In the wards, agricultural activities are practised both in the built-up and habitable places and away from people's residencies. In the areas, competition for land for agricultural and non-agricultural was also evident. Thus, these have led people to have different kinds of perception of such agricultural activities. Moreover, according to Arusha City Demographic Reports, Daraja Mbili and Lemala are occupied by 19,493 and 19,564 people, respectively. However, other wards in the Central Business District have a higher population than Daraja Mbili and Lemala. The people in such wards are not engaged in urban agriculture. Unknown information on cultural and professional perception of agriculture, as well as increased urban life hardships and the need for more land for supporting urbanization and other spatial development have made this study focus on farmers and officials within Arusha City.

\subsection{Research Design, Data Collection and Analysis}

\subsubsection{Research Design}

This study adopted a qualitative research approach to understand the respondents' ideas, opinions and perceptions of urban agriculture, the circumstance under which it is practised and its positive or adverse effects. Most of the data were collected using in-depth interviews. A case-study research design involves systematic gathering of enough information about a particular person or a social setting to have a good understanding of the person or social setting [2]. This study adopted the case study research design because the respondents' perceptions, ideas and opinions depend on the circumstances in which urban agriculture persistently takes place. The information could be obtained using indepth interviews. The study used a sample size of 60 respondents who were purposefully selected. They were selected because they could provide answers to research questions about their perception of urban agriculture. The number of the respondents was convenient as the information obtained sufficed and enabled researchers achieve the objective of the study, which was mirrored in the research variables.

\subsubsection{Data Collection and Analysis}

Data was collected from the primary source mainly using eighteen open-ended and partly through nine closed end questionnaires as well as through physical observation. The in-depth interviews were done in an investigative manner to understand the respondents' attitudes, interests and awareness with respect to urban agriculture. Secondary data was obtained from the written reports and facts at ward level. The data collected from various sources were corroborated to ensure that they were consistent. The interview data collected through audio recorder was transcribed. This was done to understand and extract meanings from it. Data analysis and synthesis were grounded in the data and the literature reviewed.

\section{Results}

\subsection{Respondents' Interests and Perception of Urban Agriculture}

In both Daraja Mbili and Lemala, all farmers perceived urban agriculture positively. They mentioned food, income, employment opportunities and physical exercise as the things that influenced their engagement in urban agriculture. They noted that agriculture employed people who could not get formal employment and do activities that require huge capital. They pointed out that agricultural activities enhanced economical use of land because the small portions of land used for crop cultivation could not all be used for construction of purpose. A farmer in Daraja Mbili said:

I perceive urban agriculture positively because it helps me to get the necessities of life. I save the money that I would otherwise use to buy food. I eat vegetables that I grow.

Another farmer in Lemala said:

By about $50 \%$, my family and I, eat the food we grow. Besides getting food from urban agriculture, I am self employed. Agricultural activities have reduced the chance of unemployed youths from becoming thieves and robbers.

The farmers' positive perception of urban agriculture was influenced by their needs which they met either directly or indirectly by doing agricultural activities.

The farmers in the two wards mentioned environmental and public health officers as stakeholders who perceived urban agriculture negatively, they considered poorly managed dung and dropping of swine and chickens as a source of bad smell in the settlements of Daraja Mbili and Lemala. The farmers were of opinions that the problems were exaggerated to forbid the practice of agriculture in the urban areas, for the waste produced was immediately used as manure in the vegetable gardens belonging to farmers who did not keep livestock, but had vegetable gardens and small farms.

The farmers pointed out that, urban planners did not care whether or not land for agricultural activities was formally allocated to urban farmers. They noted that the planners did not care because they did not regard agriculture as an important land use activity. They also mentioned that the environmental by-laws made and enforced by environmental officers at the ward level were meant to discourage agricultural activities. Farmers who violated them fined TZS 50, 0000 which they could hardly pay. Furthermore, all four agricultural officers wished to see agriculture flourish because it enabled the people including farmers to meet their livelihood needs. The in-charge of the Urban Agriculture Department of ACC mentioned that, besides the employment opportunities agriculture provided to urban farmers, it employed other people in the agricultural input-output supply chain. Agricultural officers also provided agricultural extension services to farmers, officially registered in the wards of Daraja Mbili and Lemala. The extension services were part of their responsibilities because their working stations were located at the ward level. All agricultural officers reported that they perceived agriculture positively, 
but wanted the farmers to adhere to the conditions set out in the by-laws for example of not polluting the environment or causing nuisance to other people.

The four urban planners' perception of urban agriculture depended on the manner in which it was practised. The ongoing illegal and deep ploughing of the land along the banks of Rivers Themi and Naula was perceived negatively. It was reported that, when it rained heavily, the eroded materials blocked the rivers and divert the flow of the water, which in turn flooded the adjacent settlements. Floods occurred often in the habitable areas of Darajani and Ndarvoi sub-wards in Daraja Mbili. Agricultural activities were perceived negatively because they interfered with the use of land uses for housing purposes. Other reasons for urban planners' negative perception of agriculture related to the encroachment on surveyed residential plots in the Kolongoni and Sunflag sub-ward in Lemala which had not yet been developed by the owners.

Urban planners also perceived agricultural activities negatively because they interfered with the land set aside for housing development, which was considered to produce a substantial amount of revenue after being developed compared to little revenue that could be obtained from a typical vegetable garden. By contrast, the planting of ornamental trees that control soil erosion and beautify the built-up areas of the Central Business District (CBD) was perceived positively. The interviews with all four environmental officers revealed that they supported agriculture that utilized agricultural decomposable waste as manure which could otherwise pollute the environment. It was also reported that, unguided agricultural activities still took place along the flood prone areas along Rivers Naura and Themi and on the slope of the Engra hill.

Furthermore, two of the environmental officers were neutral while two of them perceived it negatively. The environmental officer in Daraja Mbili said:

It is one of our tasks to ensure that agriculture is not a source of environmental degradation. We also recognize that the planting of trees and shrubs play a major role in environmental conservation. It is, therefore, unlikely that we will perceive it negatively. However, when agricultural activities pollute environment, we do not turn a blind eye to it. We impose fine to the culprits.

The environmental officers highly appreciate and support agricultural activities that conserve the environment compared to agricultural activities which focus solely on food production. The environmental officer in Lemala said:

The farmers always focus on their needs which are met through agriculture at the expense of the environment. They normally consider environmental conservation to have no direct benefits to them. If we (environmental officers) do not restrict agricultural activities which are not friendly to the environment, the farmers take it as an advantage, irrespective of the environmental pollution or degradation they cause. We have environmental by-laws which we use to punish people who invade the restricted areas.

It was reported by sub-ward leader in Darajani that some of the youth in the ward were temporarily allowed to use part of the road reserves in the Ally Nyanya and Jamhuri areas so that they could grow ornamental plants in containers. Moreover, a sub-ward leader in Darajani said:

A famous poultry keeper in Darajani produces a large pile of chicken manure in a month. If the chicken poop is not taken away a few days after it has been piled up, it produced an unpleasant odour, which, in turn affect the non-livestock keepers. However, as soon as it is piled up, other farmers use it as manure in their garden.

Moreover, the city environmental officers noted that urban agriculture minimizes the rate of environmental pollution by consuming the decomposable livestock waste as manure when the waste is managed promptly.

\subsection{Awareness and Perception of Urban Agriculture}

Out of the 20 farmers in Daraja Mbili, 75\% were aware that urban agricultural activities polluted and degraded the urban environment, while $25 \%$ reported that they were not. However, those who were aware observed that the extent to which agricultural activities affected the environment was exaggerated. It was also reported that people continued to cultivate vegetables along the banks of Rivers Themi and Naura because they had nowhere else to do so.

One of the farmers in Daraja Mbili said:

Most of the farmers know the adverse effects of improper agricultural activities on land and soil, but the city has not set aside alternative land for agricultural purposes. Squatting on undeveloped and prohibited public land is inevitable because agriculture help us to survive.

Although the majority of the farmers in Daraja Mbili are aware of the adverse effects of uncontrolled agricultural activities on the environment, they still perceived agriculture positively because their livelihoods depended on it. The farmers also complained that the farmers who inherited land from their grandparents were persuaded and sometimes forced to subdivide the land into residential land as if agriculture did not have any value.

In Lemala, it was revealed that $50 \%$ of the farmers were aware that urban agriculture polluted and degraded the environment and that another $50 \%$ were not. A farmer who was not aware of that questioned the importance of having undeveloped open space and bushy shrubs in certain parts of the banks of the rivers under pretext of conserving the environment. Those who were aware of the adverse of urban agriculture reported that uncontrolled agriculture greatly contributed to land degradation along the River Themi. They also reported that improper management of swine dung and chicken droppings in the congested residential areas had produced awful odour.

Seventy per-cents of the farmers in Daraja Mbili and Lemala pointed out that urban agriculture would cause few environment problems if it took place in the planned areas where agricultural officers would make sure that farmers adopted good agricultural practices. The $30 \%$ of the farmers did not see the importance of planning the land they had been farming for many years. They thought that they would be 
dispossessed under the pretext of making land use planning because the process is associated with deceitful actions.

Furthermore, four agricultural officers were aware of both the value and detrimental effects of uncontrolled agriculture on human health and the environment. The officers lead in creating awareness about good agricultural practices. They reported that, when farmers carried out agricultural activities in proper ways, there were fewer negative effects on the environment. They also noted that only agricultural activities, which did not prevent other urban land uses, could be tolerated.

When the urban planners were asked whether they were aware of the adverse effects of urban agricultural activities on the environment, all said that they were. They mentioned the soil erosion which occurred in Daraja Mbili and along the Rivers Naura and Themi. They also mentioned encroachment on public and reserved land for farming purpose along the Arusha-Kilimanjaro railway reserve. Furthermore, they reported that agricultural activities such as the growing of fodder grass which did not interfere with housing and infrastructural development were encouraged. However, the agricultural activities which did not conserve the environment were discouraged. They noted, however, that they were not responsible for promoting food crops and vegetables to improve the farmers' livelihoods. The planners questioned the contribution of agriculture to farmers' food and income because they had not seen or heard about any farmer who had become rich and who is food secure through urban agriculture. Furthermore, an urban planner expressed his opinion on urban agriculture, saying:

Owing to the competing land uses in the urban area, the use of land for agricultural purpose without justifiable socioeconomic and environmental benefits is not tolerated.

They also noted that the practising of urban agriculture on big plots should be done in the peri-urban areas or in the rural areas where there were ample land with less competition with non-agricultural uses. Through observation, the researchers saw something somewhat similar to what the urban planners mentioned. Some of the agricultural activities were done along the road reserves in Daraja Mbili as figure 1 shows.

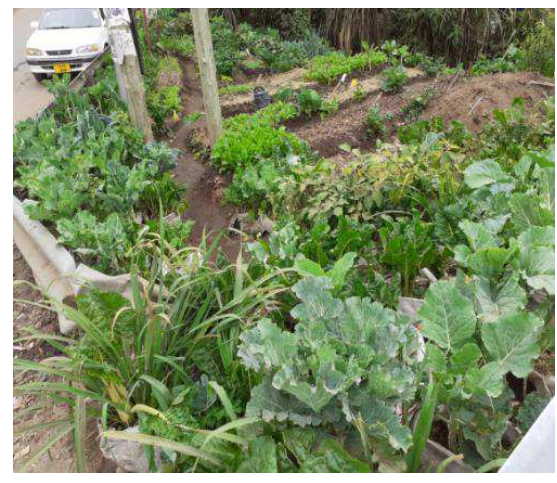

Source: Field survey, September, 2019.

Figure 1. Agricultural site in Daraja Mbili.

Agricultural activities were common along River Themi as figure 2 shows.

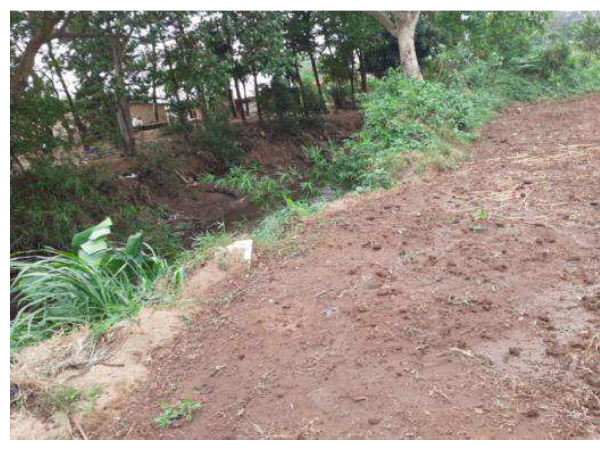

Source: Field survey, September, 2019.

Figure 2. Agricultural site in Lemala.

The four environmental officers pointed out that they were aware that urban agriculture polluted and degraded the land. However, three blamed the urban farmers' reluctance to adhere to the environmental conservation by-laws. They perceived positively the agricultural activities that conserved the environment. They also said that the promotion of food production was not included in their scheme of work. Thus, they promoted agricultural activities that contributed to environmental conservation.

Furthermore, all four sub-ward leaders were aware of the contribution of urban agriculture in terms of food and income. They were also aware of the negative and positive effects of uncontrolled agriculture on the environment. They were neutral about urban agriculture, depending of course on whether it conserved or degraded the environment. A subward leader in Kikwakwaru ' $A$ ' disliked the use of flowing water contaminated with domestic waste which comes from the local sub-streams to wash vegetables. He added that the use of sewerage water from Lemala Waste Water Ponds (LWWP) to irrigate vegetables made people who knew about that perceive urban agriculture negatively.

\section{Discussions}

The farmers in Daraja Mbili and Lemala perceived urban agriculture positively because they depend on it for food and income. Since their survival depended on agriculture, they perceived negatively the by-laws and official management practices that could put agriculture at risk. This means that their perception of urban agriculture was influenced by their dependence on it for livelihoods. The findings of this study are similar to that of Horticultural reviews [9] that one's' needs influence his or her positive perception in way that would maintain the needs. The agricultural officers' positive perception was also influenced by their professional career as promoters and facilitators of good agricultural practices in urban areas. Their profession was regarded either active or inactive through the agricultural services they provided to farmers. That might be the reason for their positive perception of urban agriculture. Monica, R. and Varsha, G. [22] note that, besides urban agriculture being perceived positively, it must also be promoted.

Agricultural officers are among those in Arusha city 
responsible for ensuring that food shortage is not critical. They could not perceive agriculture negatively because they were required to promote it. Although their efforts to promote urban agriculture were evident, they did not bear desired results sometimes, especially when farmers who received agricultural training had limited access to agricultural land. The urban planners and environmental officers perceived agriculture objectively. While the agricultural activities that protect the environment or those that did not jeopardize spatial urban land development were perceived positively, those that impaired this kind of development were perceived negatively. However, the argument by the urban planners and environmental officers that they were not food activists implies that food promotion activities are not their concern. This situation somehow contradicts with the reality that some of the food-based agricultural activities consume decomposable waste that could have polluted environment. Their perception is not directly influenced by their personal feelings. Instead it is influenced by the requirement of their employment needs. The Department of Urban Planning insists on coherent urban development, while the Environment Department focuses the protection and conservation of the urban environment. Therefore, their staff could not ignore the obligations and perceive positively uncontrolled urban agriculture. We have shown that it was the food production activities with adverse effects that were perceived negatively, instead of being rationally managed. Horst, M., McClintock, N. and Hoey, L. [12] argue that some of the environmental problems caused by urban agriculture may be addressed by providing appropriate training to farmers, doing garden planning and agricultural infrastructure.

Furthermore, the farmers in Daraja Mbili and Lemala perceived urban agriculture positively, although they knew that the cultivation of crops along the river banks caused to land degradation and that improper management of livestock waste produced an awful smell. This means that their survival needs matter so much that they do not consider protection of the environment to be important. It also means that awareness about environmental conservation can hardly influence the farmers to have negative perception of urban agriculture. Being aware that urban agriculture could place without affecting the urban environment also made agricultural officers perceive it positively and strive to make it friendly to the environment. It is stated in section 6.7.0 of the National Land Policy that agriculture is not a principal function of urban land uses, but when it is properly managed, it is a source of livelihoods of the people [32]. Some urban planners misinterpreted that agriculture is not a formal land uses while ignoring for its proper management. This on the other hand influenced their negative perception to it.

The urban planners and environmental officers were aware of agricultural activities that conserved, protected and degraded or polluted the environment. They perceived negatively the food production activities that affected the environment and non agricultural urban land development.
The findings show that their negative perception of such activities caused agricultural activities to be less promoted and supported in urban land use planning. Obosu, M. K. [25] observes that urban agriculture can be supported beyond rhetorical recognition if officials change their negative attitude toward it.

\section{Conclusions}

Urban agriculture is perceived both negatively and positively depending on the whether it affects or conserves the environment. The farmers' greatest concern was limited access to land for agricultural uses, but the officials' related to land for housing and infrastructure development and to environmental conservation. This situation shows the different interests on land which farmers and city officials have. Addressing the challenges associated with agriculture, except for access to land was among the duties of the agricultural officers. They cannot be effective when those dealing with land matters perceive urban agriculture negatively. The findings show that the needs and the expectation to meet them through agriculture made farmers to perceive agriculture in a positive way, irrespective of its adverse effects on human health and the environment. Therefore, the perception of urban agriculture has close relationship with livelihoods and the employment needs of officials such as urban planners, environmental officers and agricultural officers. The perception is also related to individual and professional interests because agriculture can have direct or indirect benefits to individuals, community members or institutions. Focusing on the welfare of the people in terms of housing, socio-economic infrastructure and the conservation of the environment by the officials while underrating agricultural activities which enabled people to meet their livelihood needs suggest that agriculture is considered less important as an aspect of urban land uses. This is indirectly related to the negative perception of agriculture. Lack of awareness and limited information about the contribution of urban agriculture to peoples' livelihoods also made the officials, especially urban planners and environmental officers perceive it negatively. This study notes that, unless awareness about food contribution of urban agriculture is raised among the city officials, they will continue to perceive it negatively. While some officials believe that the urban agricultural activities for food production or livestock keeping are antithetical to proper urban land use, there is no other human activity which can green the urban environment and immediately use of livestock waste as manure.

Changing the negative perception of urban agriculture is not easy, especially when its activities continue to interfere with other urban land use, but the proper management of agricultural activities is considered ideal. When both the negative and positive effects of agriculture are only acknowledged only in the policy and legal documents and while the practice is still perceived either in a neutral way or negatively by the officials, insignificant effort will be made 
to promote it. As consequences, its acknowledged value will eventually decline and its adverse effects increase. This, in turn, will make people perceive urban agriculture negatively forever; especially when it's adverse effects outweigh its value. In order for urban agriculture to be perceived positively and in order for it to prosper, its negative effects on human and environment should be minimized and its benefits should be increased through proper management of its associated hurdles.

\section{Conflicts of Interest}

The authors declare no conflicts of interest regarding this study.

\section{References}

[1] Appeaning, A. K. (2010). Urban and peri-urban agriculture in developing countries studied using remote sensing and in situ methods. Remote Sensing, 2 (2), 497-513.

[2] Berg, B. L. (2017). Qualitative research methods for the social sciences, California State University, Long Beach, California.

[3] Cancela, J. (2009). Urban agriculture in city planning process. The Portuguese Experience. In $45^{\text {th }}$ ISOCARP Congress [www.isocarp.net]. Site visited on $14^{\text {th }}$ September, 2018.

[4] Carr, A., Zylmans, A., Drozdzik, C., Vena, M. and Finkelstein, N. (2014). Public perceptions of urban agriculture's positionality in Vancouver, Canada. [www.lmnhs.bc.ca]. Accessed on $8^{\text {th }}$ May, 2020.

[5] Chimbwanda, F. (2016). Perceptions and attitudes of participants toward urban gardening. A case study of nutrition gardens in Mucheke Town, Masvingo. Zimbabwe Open University, (8) (8). (www.iiste.org) Site visited on $21^{\mathrm{st}}$ December, 2018.

[6] Fasth, T. (2019). Decision analysis in situations with conflicting interests; Doctoral dissertation, Stockholm University.

[7] Food and Agricultural Organization of United Nations (FAOUN). (2012). The State of Food and Agriculture: Investing in Agriculture for a Better Future [www.fao.org] Site visited on $16^{\text {th }}$ May, 2018.

[8] Freeman, D. B. (1991). A city of farmers: Informal urban agriculture in the open spaces of Nairobi, Kenya. McGillQueen's Press, Montreal, Canada.

[9] Hallett, S., Hoagland, L., Toner, E., Gradziel, T. M., Mitchell, C. A. and Whipkey, A. L. (2016). Urban agriculture: environmental, economic, and social perspectives. Horticultural reviews, 44, 65-120.

[10] Halloran, A., \& Magid, J. (2013). Planning the unplanned: incorporating agriculture as an urban land use into the Dar es Salaam Master Plan and Beyond. Environment and Urbanization, 25 (2), 541-558.

[11] Hamisi, R. (2012). Contribution of urban agriculture to food security: A case study of Sombetini, Daraja Mbili, and Sokon one wards, in Arusha city, University of University of Dar es Salaam, School of Law, Tanzania.
[12] Horst, M., McClintock, N. and Hoey, L. (2017). The intersection of planning, urban agriculture, and food justice: A review of the literature. Journal of the American Planning Association, 83 (3), 277-295.

[13] Ives, C. D \& Kendal, D. (2013). Values and attitudes of the urban public towards peri-urban agricultural land. Land use policy, 34, 80-90.

[14] Kopiyawattage, K. P., Warner, L. and Roberts, T. G. (2019). Understanding urban food producers' intention to continue farming in urban settings. Urban agriculture \& regional food systems, 4 (1), 21-37.

[15] Kutiwa, S., Boon, E., \& Devuyst, D. (2010). Urban Agriculture in low income households of Harare: an adaptive response to economic crisis. Journal of Human Ecology, 32 (2), 85-96.

[16] Lee-Smith, D. (2010). Cities feeding people: an update on urban agriculture in Equatorial Africa. Environment and Urbanization, 22 (2), 483-499.

[17] Lovell, S. T. (2010). Multifunctional urban agriculture for sustainable land use planning in the United States. Sustainability, 2 (8), 2499-2522.

[18] Magigi, W. (2013). Urbanization and its impacts to food systems and environmental sustainability in urban space: Evidence from urban agriculture livelihoods in Dar es Salaam, Tanzania. Journal of environmental protection. 13, 1138-1148.

[19] Magigi. W. (2008). Improving urban land governance with emphasize of integration of urban agriculture based livelihoods in spatial land use planning practices in Tanzania. Freiburg im Breisgau, Germany.

[20] McClintock, N; Miewald, C., \& McCann, E. (2018). The politics of urban agriculture: Sustainability, governance and contestation. In the Routledge handbook on urban space politics, 361-374.

[21] Mkwela, H. S. (2013). Urban agriculture in Dar es Salaam: a dream or reality?. Sustainable Development and Planning VI, $173,161$.

[22] Monica, R. and Varsha, G. (2018). Transforming urban farming approaches to achieve the SDGs. [www.oaji.net/articles]. Site visited on $9^{\text {th }}$ August, 2020.

[23] Mosha, A. C. (2015). Urban Agriculture in Botswana. Commonwealth Journal of Local Governance, 48-67.

[24] Nuhu, S. (2018). Peri-Urban Land Governance in Developing Countries: Understanding the Role, Interaction and Power Relation among Actors in Tanzania. In Urban Forum, Springer Netherlands.

[25] Obosu, M. K. (2002). Changes in official attitudes towards urban agriculture in Accra. African Studies Quarterly, 6 (3), 19-32.

[26] Okoro, E., Tarinabo, I. N., Ibe, A. H. and Martin, N. C. (2017). Environmental and economic perception of urban farming in Aba, Nigeria. International journal of environmental chemistry, 2 (5), 73-80.

[27] Owusu, V., Bakang, J. E. A., Abaidoo, R. C. and Kinane, M. L. (2012). Perception on untreated wastewater irrigation for vegetable production in Ghana. Environment, development and sustainability, 14 (1), 135-150. 
[28] Poulsen, M. (2015). They got corn out here in the heart of the Ghetto? Community perceptions of urban farming in Baltimore, Maryland. Doctoral Dissertation, at Johns Hopkins University. [jscholarship.library.jhu.edu] Site visited on $29^{\text {th }}$ January 2020.

[29] Quon, S. (1999). Planning for urban agriculture: A review of tools and strategies for urban planners. Cities feeding people series; 28 . Accessed on $11^{\text {th }}$ September, 2018.

[30] Schmidt, S. (2012). Getting the policy right: urban agriculture in Dar es Salaam, Tanzania. International Development Planning Review, 34 (2), 129-145.

[31] Sharma, V. P. (2015). Dynamics of land use competition in India: Perceptions and realities. [www.vslir.iima.ac.in]. Accessed on $17^{\text {th }}$ July, 2020.

[32] United Republic of Tanzania (URT). (1995), National Land Policy, The Ministry of Lands, Housing and Human Settlement Development, Tanzania.
[33] United Republic of Tanzania (URT). (2000), National Human Settlements Development Policy, The Ministry of Lands, Housing and Human Settlements Development, Tanzania.

[34] United Republic of Tanzania (URT). (2007). Land Use Planning Act, 2007. Government Printer, Dar es Salaam.

[35] United Republic of Tanzania (URT). (2018). The Urban Planning (Urban Farming) Regulations, The Ministry of Lands, Housing and Human Settlements Development, Tanzania.

[36] Wegedie, K. T. (2018). The Impact of urban expansion on the livelihood of farming communities in peri-urban area of Bahir Dar City Amahara, Ethiopia. Journal of Economics and Sustainable Development, 9 (9).

[37] Zeeuw, H., Guendel, S., \& Waibel, H. (2000). The integration of agriculture in urban policies. Growing cities, growing food. Urban Agriculture policy 161-180. 